\title{
Interkoneksi Konsep Walimah Perkawinan dalam Hukum Islam dan Hukum Adat Bugis Bone
}

\author{
Hamzah $^{1}$ \\ Fakultas Syariah dan Hukum Islam IAIN Bone, Jl. Hos Cokroaminoto. \\ Email: ${ }^{1}$ hamzahlatif122@gmail.com
}

\begin{abstract}
This study emphasized the interconnection between the concepts of Islamic law and customary law in the marriage ceremony. The focus of this study examined the concept of marriage in Islamic law and customary law, as well as the interconnection between Islamic law and the custom of marriage in Bugis Bone. This study was a descriptive analytical which described the sources obtained and then analyzed. The researcher applied normative and historical social approaches. Comparative methods were used to analyze various data and then correlated one another. This was conducted to measure the interconnection of Islamic law and customary law, therefore the relevant and irrelevant elements can be identified. The results of this study proved that the concept in the implementation of the marriage ceremony showed correlation between Islamic law and customary law of Bugis Bone. Both are considered not contradictory, even the procession of the marriage in Bugis Bone tradition has philosophical values that are in line with the principles of Islamic law.
\end{abstract}

Keywords: Marriage ceremony-Islamic Law-Customary Law.

\begin{abstract}
Abstrak
Kajian ini menekankan pada interkoneksi konsep hukum Islam dan hukum adat dalam pelaksanaan walimah perkawinan. Fokus dalam kajian ini menelaah konsep walimah perkawinan dalam hukum Islam dan hukum adat masyarakat Bugis Bone, serta interkoneksi hukum Islam dan adat Bugis Bone dalam walimah perkawinan. Kajian ini bersifat deskriftif analitis, yakni menguraikan sumbersumber yang diperoleh dan kemudian dianalisis. Pendekatan dalam kajian ini di antaranya normatif dan sosial historis. Metode komparasi digunakan untuk manganalisa data yang beragam dan kemudian menganalisa satu dengan yang lainya. Hal itu dilakukan untuk mengukur interkoneksi hukum Islam dan hukum adat, sehingga dapat diketahui unsur-unsur yang relevan dan tidak relevan. Hasil kajian ini membuktikan bahwa konsep pelaksanaan walimah perkawinan, terdapat korelasi hukum Islam dan hukum adat Bugis Bone. Keduanya dianggap tidak bertentangan, bahkan prosesi pelaksanaan walimah Bugis Bone memiliki nilainilai filosofis yang sejalan dengan prinsip-prinsip hukum Islam.
\end{abstract}

Kata Kunci: Walimah-Hukum Islam-Hukum adat. 
Hamzah:

"Interkoneksi Konsep Walimah Perkawinan dalam Hukum Islam dan Hukum Adat Bugis Bone"

\section{Pendahuluan}

Walimah perkawinan" atau wali>ma al-'ursy. Dalam bahasa Indonesia disebut acara pesta atau acara resepsi perkawinan. Kata walimah yang sudah diserap kedalam bahasa Indonesia secara sederhana dapat diartikan sebagai perayaan, baik berupa perayaan pesta perkawinan maupun perayaan acara berupa aqi>qah dan sejenisnya. Walimah sering diidentikkan dengan perayaan pesta perkawinan, sehingga kata walimah sangat populer dengan perayaan pesta perkawinan. Tujuan mengadakan walimah adalah untuk memberikan informasi masyarakat luas akan keabsahan sebagai suami istri.

Alquran sebagai sumber utama hukum Islam, tidak memberikan informasi terkait dengan term walimah. Namun dalam hadis Rasulullah menggambarkan anjurkan walimah. Hal itu tergambar dalam hadis yang diriwayatkan oleh Anas bin Malik, bahwa:

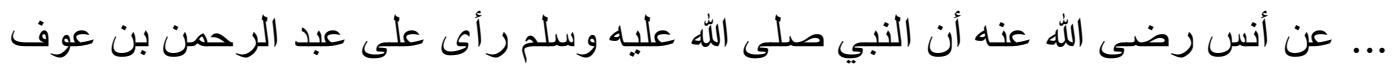

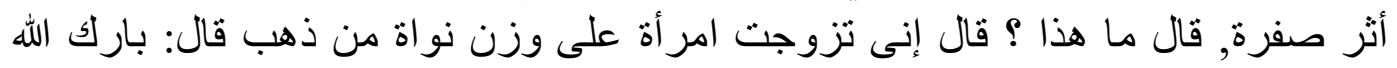

للك أولم ولو بشاة (رواه البخري). Artinya: ...dari Anas r.a. bahwasanya Nabi saw. melihat pada diri Abd Rahman bin Auf wangi-wangian, Nabi bertanya: untuk apa itu? Abd Rahman menjawab: saya telah mengawini seorang wanita dengan biji-bijian setimbang emas, Nabi bersabda: semoga Allah memberi berkah adakanlah perjamuan (walimah) sekali pun dengan seekor kambing'.

Hadis yang diriwayatkan oleh Anas bin Malik tersebut cukup populer dikalangan ahli hadis maupun para ahli tafsir. Hadis tersebut berkualitas shahih, namun bentuk pengamalannya tidak mendapat respon di kalangan masyarakat muslim.

Kenyataan menunjukkan bahwa pesta perkawinan di era modern ini, termasuk hukum adat Bugis Bone banyak dilaksanakan di gedung-gedung dengan menu-menu yang disediakan cukup megah dan mewah. Paradigma mereka tentang ukuran kuantitas adalah menu-menu yang harganya lebih mahal dari kambing. Di sisi lain, yang menjadi ukuran kualitas adalah mewah dan meriahnya. Pelaksanaan walimah tidak merasa lengkap tanpa adanya hiburan-hiburan seperti elekton dan sejenisnya, karena ukuran kualitasnya adalah maraknya. Bila ditilik

${ }^{1} \mathrm{Abu}>$ Abdillah Muhammad Ismai>l al-Bukha>ri, Shahih al-Bukhari Jilid 3 (Bairut Libanon: al-Makiyyah, t.h.), h. 254. Hadis tersebut diriwayatkan oleh muttafaku alaih sebagaimana dikatakan Abu Bakar Jabir Al-Jazairi, yang dikutif dalam bukunya Ensikliopedi Muslim Minhajul Muslim (Cet. I Jakarta Timur: Darul Fikr, Beirut, Rajab 1421 H./ Oktober 2000), h. 580 
Hamzah:

"Interkoneksi Konsep Walimah Perkawinan dalam Hukum Islam dan Hukum Adat Bugis Bone”

pelaksanaan resepsi perkawinan, saat ini dilaksanakan dalam jamuan makan yang bertaraf mewah dan megah. Maka, kedudukan hadis sebagai sumber hukum Islam menjadi terimarjinalkan sebagai pedoman dalam perayaan walimah perkawinan.

Adat Bugis Bone merupakan daerah di Sulawesi Selatan yang memiliki hukum adat kuat, yang dipegang teguh oleh masyarakatnya. ${ }^{2}$ Paham masyarakat akan adat sangat kental. Pelaksanaan walimah yang tidak sesuai dengan adat istiadat yang berkembang dalam masyarakat, maka akan mendapat sanksi sosial. Budaya walimah di Kabupaten Bone banyak dipengaruhi oleh adat istiadat yang sedikit kontradiksi dengan makna hadis. Kajian ini dimaksudkan untuk membuka wacana dan wawasan keislaman, khususnya dalam interkoneksi hukum Islam dan hukum adat perihal walimah perkawinan di masyarakat Bugis Bone.

\section{Metodologi}

Kajian ini termasuk dalam kategori penelitian pustaka (liberari research). Menelaah dan meneliti terhadap sumber-sumber kepustakaan, Alquran, as-sunnah, kitab-kitab fikih dan buku-buku hukum adat yang berkaitan dengan adat perkawinan masyarakat Bugis Bone. Kajian ini bersifat deskriftif analitis, yakni menguraikan sumber-sumber yang diperoleh dan kemudian dianalisis. Pendekatan dalam kajian ini di antaranya: (1) normatif, yakni pendekatan yang dapat menuju kapada persoalan dapat tidaknya sesuatu dipergunakan sesuai dengan ketentuan syariat Islam; (2) sosial historis yang dapat memberikan informasi tentang keadaan sosial masyarakat. Metode komparasi digunakan untuk manganalisa data yang beragam dan kemudian menganalisa satu dengan yang lainya. Hal itu dilakukan untuk mengukur interkoneksi hukum Islam dan hukum adat, sehingga dapat diketahui unsur-unsur yang relevan dan tidak relevan.

\section{Pembahasan}

${ }^{2}$ Lihat, Abdurahman, Hukum Adat Menurut Perundang-Undangan Refublik Indonesia, Edisi I (Cet. I; Jakarta: Cendana Press, 1984) h. 20. Dikutif dalam penelitian H. Syarifuddin Latif, Status Hukum Pernikahan Wanita Hamil di Luar Nikah dan Anaknya Perspektif Hukum Adat dan Hukum Islam (Cet. I; Yongyakarta: CV Orbittrust Corp, 2012), h. 25. 
Hamzah:

"Interkoneksi Konsep Walimah Perkawinan dalam Hukum Islam dan Hukum Adat Bugis Bone"

\section{Konsep Walimah Perkawinan dalam Hukum Islam}

Walimah dalam kamus dari kata الوليمة (jamuan, pesta), وليمة العرش (pesta

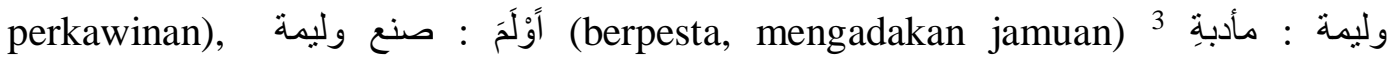
(perjamuan, pesta, makan-makan) ${ }^{4}$. Pesta perkawinan atau disebut juga dengan "walimah"5 adalah pecahan dari kata ولم artinya mengumpulkan. Karena dengan pesta tersebut dimaksudkan untuk memberi doa restu agar kedua mempelai bertemu dengan rukun. ${ }^{6}$ Ensiklopi Hukum Islam menerangkan bahwa al-walimah adalah berkumpul karena pada waktu itu kedua mempelai dipersandingkan, al-'ursy adalah perkawinan.

Menurut Sayyid Sabiq, arti walimah adalah berkumpul, sebab pada waktu itu suami istri akan berkumpul. ${ }^{7}$ Istilah dalam kamus, walimah adalah makanan-makanan acara pesta perkawinan yang disediakan para tamu undangan. ${ }^{8}$ Walimah juga berarti jamuan khusus yang diadakan dalam perkawinan atau setiap jamuan pesta lainnya. Tetapi biasanya kalau menyebut walimah al-'ursy artinya perayaan pernikahan. ${ }^{9} \mathrm{Jadi}$, walimah perkawinan merupakan acara pesta perkawinan berupa jamuan makan, yang dilaksanakan sebagai bentuk syukur kepada Allah swt. atas terjalinnya hubungan yang sah (akad nikah).

Hukum Islam dalam menjelaskan konsep walimah, merujuk hadis Rasulullah yang diriwayatkan Anas bin Malik. Klausal (أولم ولو بشاة) dipahami adanya petunjuk untuk melaksanakan walimah bagi yang mempunyai

${ }^{3}$ Ahmad Warso Munawir, Kamus Arab Indonesia (t.c. Yongyakarta: Pustaka Progressif, 1984), h. 1689.

${ }^{4}$ Atabik Ali dan A. Zuhdi Muhdlor, Kamus Kontemporer Arab Indonesia (Cet. VIII; Yongyakarta: Multi Karya Grafika, 2003), h. 2041.

${ }^{5}$ Walimah (pesta) itu merupakan bermacam-macam, setiap walimah memiliki nama tersendiri, akan tetapi istilah walimah itu sendiri besifat mutlak untuk walimah al- ursy (pesta pernikahan), adapun Walimah Khurs ialah istilah untuk selamatan atas kelahiran anak. Walimah I'dzar istilah untuk pesta khitam, Walimah Aqiqah istilah untuk pesta kelahiran anak, Walimah Wakirah istilah pesta untuk bangunan, Walimah Naqi'ah istilah untuk pesta kedatangan musafir, Walimah Wakariah istilah untuk pesta pembaharu bangunan, walimah Wadhimah istilah untuk selamatan agar terhindar dari musibah, Walimah Ma'diyah istilah untuk pesta yang dilakukan tanpa ada sebab. Semua walimah tersebut disunnahkan: Al-Raudah: 7/332; al-Muhadhab; 4/223; al-Majmu; 17/75; Mughni al-Mauhtaj: 3/244-245; al-Hawi: 12/190 dikutif dari: Muhammad Zuhaly, Fikih Munakahat Kajian Fiqih Pernikahan dalam Perspektif Mazhab Syafi'I ( Cet. I; Surabaya: CV Imtiyaz, 2013), h. 160-161

${ }^{6}$ Ibrahim Muhammad al-Jamal, Fiqih Wanita (Terjemahan Anshori Umar) (Cet. I; Semarang: CV. Asy-Syifa', 1986), h. 382

${ }^{7}$ Sayid Sabiq, Fiqh as-Sunnah Jilid II (Cet. VIII; Bairut Kitab al-Arabi, 1987 M atau $1407 \mathrm{H})$, h. 210.

${ }^{8}$ Sayyid Sabiq, Fiqih Sunnah Jilid II, h. 210.

${ }^{9}$ Sayyid Shabiq, Fiqih Sunnah Jilid II, h. 210. 
Hamzah:

"Interkoneksi Konsep Walimah Perkawinan dalam Hukum Islam dan Hukum Adat Bugis Bone"

kesanggupan, dibidang ekonomi maupun kekuatan mental. Pelakana walimah, Nabi menganjurkan dengan ukuran minimal (kesederhanaan) dalam pesta perkawinan. Kesederhanaan dalam melaksanakan perjamuan, termasuk pesta tidak bermewah-mewah atau menghambur-hamburkan harta. Hal itu sejalan dengan QS. al-Isra/17: 27:

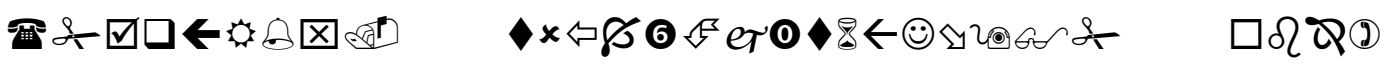

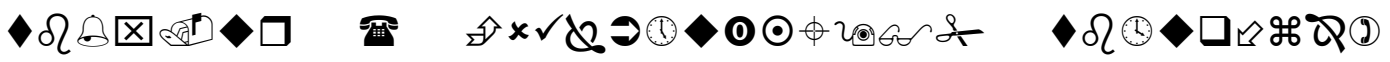

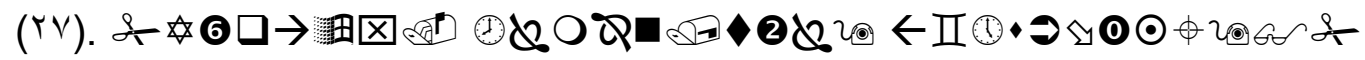

Terjemahnya:

Sesungguhnya pemboros-pemboros itu adalah saudara-saudara syaitan dan syaitan itu adalah sangat ingkar kepada Tuhannya. ${ }^{10}$

Dalam QS al-Isra/17:27 bermaksud bahwa, pelaksanaan walimah tidak boleh berlebih-lebihan. Mengadakan jamuan walimah tidak terlepas dari norma-norma Islam dan tidak mengedepankan sifat kemubaziran karena hal itu menyerupai setan dan termasuk perbuatan ingkar kepada Allah swt.

Klausa “" أولم ولو بشاة", sebagai anjuran untuk mengadakan jamuan makan (walimah), sekali pun dengan memotong sekor kambing, karena secara antropologis kambing pada saat hadis Nabi disabdakan merupakan peliharaan sehari-hari bangsa Arab. Lafaz " لو ", berarti bukan menunjukkan fungsi al-intina'iyah (larangan atau mencegah), tapi menunjukkan kuantitas minimal dalam pelaksanaan resepsi perkawinan (walimah). ${ }^{11}$

Lafaz "وأولم" " berasal dari kata " لوليمة", diartikan sebagai berkumpul, 12 karena kedua mempelai (suami istri) dipersandingkan. Walimah dalam bahasa Indonesia mengandung makna; pertama, seluruh perayaan yang melibatkan orang banyak, dan kedua, peresmian perkawinan yang bertujuan memberitahukan khalayak ramai bahwa kedua mempelai telah sah menjadi suami istri, sekaligus sebagai rasa syukur keluarga kedua belah pihak atas berlangsungnya perkawinan tersebut. ${ }^{13}$

${ }^{10}$ Kementerian Agama, Alquran dan Terjemahnya, h. 284

${ }^{11}$ Ahmad bin Ali bin Hajar al-Asqalani, Fath al-Bari, h. 235 dan Abu al-Thayyib Muhammad Syams al-Haq Abadi, Aun al-Ma'bud Aun al-Ma'bud, h. 140.

${ }^{12} \mathrm{Abu}$ Zakariya Yahya bin Syaraf al-Nawawiy, Shahih Muslim bin Syarh alNawawiy, jilid IX (Mesir: al-Matba'ah al-Misriyah, 1924), h. 216. Lihat pula Abu al-'Ala Muhammad bin Abd. Rahmanbin Abd. Rahim al-Mubarakfuriy, Muqaddimah Tuhfah alAhwaz, jilid III (Madinah: Maktabah al-Salafiyah, 1387 H/1967 M), h. 375.

${ }^{13}$ Ahmad bin Ali bin Hajar al-Asqalani, Fath al-Bari, h. 240. 
Hamzah:

"Interkoneksi Konsep Walimah Perkawinan dalam Hukum Islam dan Hukum Adat Bugis Bone"

Menurut Ibnu Atsir bahwa walimah, yaitu jamuan makan (pesta) atau tiap-tiap pesta yang menghidangkan makan dan semacamnya. Al-Iyadh menambahkan, walimah yaitu perjamuan makan (pesta) dalam perkawinan. Imam Syafi'i berpendapat bahwa semua pesta yang menunjukkan kegembiraan kepada yang baru seperti pernikahan dan khitanan. ${ }^{14}$

Penetapan Nabi saw. untuk melaksanakan perjamuan makan atau resepsi perkawainan. Seandainya tidak disebutkan sekalipun seekor kambing oleh Nabi, maka akan dipahami adalah kemutlakan seekor kambing, berarti yang lain tidak boleh. Namun demikian, menurut Abu Dawud bahwa perintah ini hanyalah ditujukan kepada Abd. Rahman secara pribadi dan yang lain boleh saja. ${ }^{15}$

Menurut al-Iyadh, kadar minimal pelaksanaan resepsi perkawinan, yaitu disesuaikan dengan kesanggupan dan kondisi ekonomi suami sebagai pelaksana pada acara tersebut. Imam Syafi'i mengatakan bahwa perintah untuk memotong seekor kambing hanyalah ditujukan kepada diri pribadi Abd. Rahman, sebab Nabi tidak pernah meninggalkan pesta dan dari perintah itu menunjukkan adanya usaha untuk melaksanakan walimah (pesta) sesuai kemampuan. ${ }^{16}$ Sebagai penolakan batas minimal memotong seekor kambing, salah satu pendapat bahwa hanyalah merupakan anjuran untuk melaksanakan walimah. Penetapan Nabi saw. untuk memotong kambing bukanlah kemutlakan, akan tetapi masih disesuaikan dengan kondisi ekonomi dan adat dalam suatu masyarakat.

Walimah atau resepsi lazim dikaitkan dengan acara perjamuan makan atau pesta dalam perkawinan (walimah al-ursy). Akan tetapi bila ditinjau lebih dalam lagi, maka makna walimah mempunyai makna yang lebih luas. Makna walimah tersebut disinonimkan pada setiap acara jamuan makan. Hal inilah yang mendasari al-Nawawi dan Abi al-Iyadh membagi walimah, di antaranya: (a) walimah khitanan; (b) aqiqah kelahiran; (c) aqiqah hari ketujuh; (d) pesta rujuk dari perceraian (talak); (e) rumah baru; (f) menyambut datang perantau; (g) di timpa musibah; dan (h) jamuan makan tanpa sebab tertentu. ${ }^{17}$ Dari acara tersebut, dalam masyarakat tidak

${ }^{14}$ Ahmad bin Ali bin Hajar al-Asqalani, Fath al-Bari, h. 241.

${ }^{15} \mathrm{Abu}$ al-Thayyib Muhammad Syams al-Haq Abadi, Aun al-Ma'bud Aun alMa'bud, h. 140 .

${ }^{16}$ Ahmad bin Ali bin Hajar al-Asqalani, Fath al-Bari, h. 225.

${ }^{17}$ Ahmad bin Ali bin Hajar al-Asqalani, Fath al-Bari, h. 225. 
melupakan sajian perjamuan bersama. Atas dasar inilah, dipahami bahwa term walimah dikaitkan pada setiap acara perjamuan makan. Namun demikian kenyataan dalam masyarakat setiap kali mengadakan acara jamuan makan tidak disebut sebagai walimah dalam arti pesta yang lebih spesifik.

Kuantitas walimah perkawinan yang mengisahkan pada diri Abd. "أولم " Rahman bin Auf dapat ditari beberapa kandungan hukum. Lafaz adalah perintah (fiil amr), bila teksual dipahami adalah kewajiban melaksanakan walimah. Akan tetapi, mengadakan pesta perkawinan itu hanyalah merupakan anjuran, karena tidak semua orang mampu melakukannya, tergantung pada kemampuan ekonomi bagi kedua belah pihak, khususnya bagi suami. Memotong seekor kambing, dipahami menunjukkan kadar minimal perjamuan makan dalam pesta perkawinan. Hal ini pula menunjukkan perlunya diadakan pesta, sebagai rasa kesyukuran bagi keluarga mempelai.

Maka kuantitas walimah perkawinan dalam hukum Islam, dipahami sebagai anjuran Nabi saw., untuk melaksanakan jamuan makan dalam perkawinan. Tanda rasa syukur dan sarana silaturrahim bagi sesama. Kadar kuantitas pelaksanaan walimah tergantung pada kesanggupan bagi kedua mempelai (suami istri), dan lebih khusus lagi bagi calon suami.

\section{Konsep Walimah Perkawian dalam Huku Adat Bugis Bone}

Secara sosial kultural bahwa orang Bugis Bone sangat menjunjung tinggi nilai budaya yang berkembang di tengah-tengah masyarakat. Hal itu dianggap sebagai siri' (malu) ketika kebiasaan berkembang tidak dijalangkan, maka tidak lepas dari sanksi sosial. Budaya Mappakeade (penghormatan kepada adat) melekat pada pribadi masyarakat, sebagai hukum adat Bugis Bone.

Prosesi walimah perkawinan adat Bugis Bone begitu panjang. Pesta perkawinan adat istiadat daerah Bone sejak dahulu ditempuh dengan melalui beberapa tahapan, meskipun dalam pelaksanaannya sedikit demi sedikit mengalami pergeseran. Tetapi hal-hal yang sifatnya prisipil masih tetap dilakukan. Sebelum acara perkawinan dilangsungkan, maka ada beberapa pase yang dilalui. Pase-pase tersebut adalah sebagai berikut:

(a) Pra Perkawinan 
Langka awal dari proses penyelenggaraan perkawinan adalah paita, artinya melihat, memantau atau mengamati dari jauh mabbaja laleng (membuka jalan). ${ }^{18}$ Langkah kedua yang dilakukan Mammanu'manu' artinya melakukan kegiatan seperti burung yang terbang kesana kemari. Tujuannya adalah untuk menemukan seorang gadis yang kelak akan dilamarnya. Setelah menemukan seorang gadis yang menurut pertimbangan bisa dijadikan istri oleh anaknya, dilanjutkan kegiatan ini kepada langkah selanjutnya yang disebut Mappese' pese'. ${ }^{19}$ Kemudian dilanjutkan Madduta/ Massuro.

Meminang dalam bahasa Bugis disebut Massuro atau Madduta yakni mengutus beberapa orang ke rumah perempuan yang akan dilamar. ${ }^{20}$ Malamar atau meminang adalah kelanjutan daripada tahap pertama (Mappese'pese'). Proses ini diterimah maka dilanjutkan Mappetu Ada', ini dilaksanakan dalam bentuk dialog antara juru bicara pihak laki-laki dengan juru bicara pihak perempuan. Dalam acara mappetu ada' sudah tidak ada lagi perselisihan pendapat karena memang sudah dituntaskan segala sesuatunya sebelum mappetu ada'. Acara ini dilakukan dengan mengundang keluarga, handai taulan, tetangga dan lain sebagainya. ${ }^{21}$ Pada fase ini sduah ada bentuk pesta, namun sifatnya masih sederhana.

(b) Persiapan Perkawinan

Persiapan perkawnian di antaranya; Mappuada atau mattampa (mengundang) dilakukan baik oleh pihak laki-laki maupun pihak perempuan untuk memberi informasi kepada segenap keluarga, handai tolan. Dilanjutkan Mabbaruga/Massarapo, budaya perkawinan masyarakat Bugis Bone, mabbaruga atau mendirikan baruga (massarapo) merupakan salah satu rangkaian dari prosesi perkawinan yang penting. Dikatakan demikian karena mabbaruga diadakan untuk menampung undangan keluarga dan undangan resmi. Mappasau dan Cemme Passili (Mandi Sauna dan Tolak Bala) berarti merawat pengantin. Kegiatan ini dilakukan dalam satu ruangan

${ }^{18}$ Syarifuddin Latif, Budaya Perkawinan Masyarakat Bugis Tellumpoccoe Perspektif Hukum Islam (Disertasi, Program Pascasarjana Universitas Islam Negeri Alauddin Makassar, 2008), h. 190-191.

${ }^{19}$ Asmat Riady Lamallongeng, Dinamika Perkawinan Adat dalam Masyarakat Bugis Bone (Dinas Kebudayaan dan Pariwisata, 2007), h. 11.

${ }^{20}$ Asmat Riady Lamallongeng, Dinamika Perkawinan Adat dalam Masyarakat Bugis Bone, h. 12.

${ }^{21}$ Abd. Kadir Ahmad MS, Sistem Perkawinan di Sulawesi Selatan dan Sulawesi Barat, h. 140. 
Hamzah:

"Interkoneksi Konsep Walimah Perkawinan dalam Hukum Islam dan Hukum Adat Bugis Bone"

tertentu selama tiga hari berturut-turut sebelum hari " $\mathrm{H}$ " perkawinan. Kemudian Tudang Penni yang terdapat duan acara yakni Mappanré Temme (khatam alQuran) dan Barazanji dan Mappacci. ${ }^{22}$ Pada fase-fase di atas dalam adat Bugis Bone sudah berbentuk jamuan makan yang sifatnya kekeluargaan.

(c) Proses Pelaksanaan Perkawinan (Tudang Botting)

Secara garis besar, upacara atau resepsi perkawinan dibagi menjadi dua tahap yaitu Mappénré Botting dan Marola Botting. Mappénré botting adalah mengantar mempelai pria ke rumah mempelai wanita untuk melaksanakan beberapa serangkaian kegiatan seperti madduppa botting, akad nikah, dan mappasiluka. Madduppa Botting (menyambut kedatangan pengantin) berarti menyambut kedatangan mempelai pria di rumah mempelai wanita untuk melakukan akad nikah. Ijab qabul dimulai dengan khutbah nikah oleh imam atau penghulu. Kemudian mempelai pria duduk berhadap-hadapan dengan imam atau penghulu sambil berpegangan ibu jari (jempol) tangan kanan. Dengan bimbingan imam, mempelai pria mulai mengucapkan beberapa bacaan seperti istigfar, dua kalimat syahadat, shalawat, dan ijab qabul. Sighat atau kalimat ijab qabul yang disampaikan oleh mempelai pria harus jelas kedengaran oleh para saksi untuk sahnya akad nikah. Oleh karena itu, tak jarang mempelai pria harus mengulanginya hingga dua tiga kali. ${ }^{23}$

Setelah proses akad nikah selesai, mempelai pria dituntun oleh orang yang dituakan menuju ke dalam kamar mempelai wanita untuk Mappasikarawa atau Mappasiluka (persentuhan pertama). Dan kemudian kedua mempelai duduk bersanding di pelaminan, selanjutnya diadakan acara nasehat perkawinan. Selanjutnya upacara mappénré botting ditutup dengan upacara jamuan santap bersama.

Acara selanjutnya Marola atau mapparola adalah kunjungan balasan dari pihak mempelai wanita ke rumah mempelai pria. Pengantin wanita diantar oleh iring-iringan yang biasanya membawa hadiah sarung tenun untuk keluarga suaminya. Setelah mempelai wanita dan pengiringnya tiba di rumah mempelai

${ }^{22}$ Mappacci berasal dari kata paccing yang berarti bersih. Mappacci berarti membersihkan diri. Maksudnya agar calon pengantin itu terhindar dari segala sesuatu yang dapat menghambat acara pernikahan. Selain itu, calon pengantin dengan hati yang bersih menghadapi segala rangkaian acara pernikahan, termasuk pula bersih diri dalam mengarungi hidup berkeluarga. Acara mappacci disebut juga acara tudampenni yang dilakukan di rumah masing-masing kedua calon mempelai. Sebuah acara tudang penni terlebih dahulu diadakan upacara penganmbilan pacci yang disebut malekke pacci.

${ }^{23}$ Cristian Pelras, Manusia Bugis (Jakarta: Forum Jakarta-Faris École Français, 2006), h. 183. 
Hamzah:

"Interkoneksi Konsep Walimah Perkawinan dalam Hukum Islam dan Hukum Adat Bugis Bone”

pria, mereka langsung disambut oleh seksi padduppa (penyambut) untuk kemudian dibawa ke pelaminan.

Seluruh rangkaian itu, sudah melakukan jamuan yang sudah menyeduhkan berbagai makanan dalam prosesi walimahnya. Bahan-bahan dan perlengkapan dalam proses perkawinan masyarakat Bugis Bone pada umumnya terdiri dari; (1) Makanan disuduhkan pada walimah masyarakat Bugis Bone tidak lengkap tanpa memotong sapi sebagai menu utama dalam prosesi pernikahannya. Selebihnya makanan-makanan pelengkap lainya sperti ayam, acara', paccala, doko-doko, dan lain-lain, yang telah dibuat oleh jennang (juru masak/koki); dan (2) Makanan kue berupa kue-kue tradisional Bugis seperti onde-onde, beppa puteh, nennu-nennu, palopo, barongko, paloleng, sanggara, lapisi, cangkuli, banddang-banddang, indo beppa, beppa bangke, sokko dan masih banyak kue-kue lainnya.

Pelaksanaan walimah al-'ursy adat masyarakat Bugis Bone membutuhkan waktu yang lama sekitar empat sampai dua minggu. Banyak hal yang harus dilengkapi sebagaimana yang telah disebutkan di atas. Di samping kelengkapan adat istiadat yang harus ditunaikan dan beberapa rangkaian acara lainya. Kesemuanya ini dianggap urgen dalam walimah masyarakat Bugis Bone. Pelaksanaan walimah pada masyarakat Bugis Bone lebih diutamakan kemeriahannya. Karena sebuah bentuk malu (masiri) ketika pelaksanaan walimah dengan tidak meriah, sehingga mulai dari pelaksanaan adat istiadat walimah perkawinan sampai kepada resepsinya dilaksanakan dengan maksimal. Adat pesta perkawinan Bugis Bone, salah satu disuduhkan adalah hiburan berupa elekton dan karaoke. Hiburan diaggap pelengkap kemeriahan pesta dan selalu dianggap kurang tanpa adanya bunyi-bunyian yang mengiringan acara pesta perkawinan.

Walimah perkawinan masyarakat Bugis Bone tidak lepas dari sikap siri', maka tidak salah ketika pelaksanaan walimah terkesan dipaksakan, dan memakan dana yang tidak sedikit. Hal ini sangat teguh dipegangnya demi memperjuangkan tegaknya adat. Karena kondisi demikan menjadi sanksi sosial tatkalah walimah yang dilakukan berkesan tidak meriah. Bahkan dianggap sebagai perkawinan masolang/makkasolang. Sehingga pelaksanaan walimah diupayakan semeriah mungkin demi mempertahankan adat sekaligus menghidari anggapan miring yang bisa menjatuhkan martabak keluarga (mappakasiri).

\section{Interkoneksi Hukum Islam dan Hukum Adat Bugis Bone dalam Konsep Walimah}


Hamzah:

"Interkoneksi Konsep Walimah Perkawinan dalam Hukum Islam dan Hukum Adat Bugis Bone"

(a) Hukum Pelaksanaan Walimah

Hukum pelaksanaan walimah dalam hadis أولم ولو بشاة sebagaimana dijelaskan sebelumnya bahwa ada dua pendapat yakni jumhur ulama mangatakana bahwa walimah perkawinan hukumnya sunnah, dan ulama alZahiriyyah mengatakan wajib. Perbedaannya dalam memahami hadis Nabi yang diriwayatkan oleh Anas “أولم ولو بشاة". Menurut Jumhur Ulama, sekalipun Rasulullah saw. dalam sabdanya itu menggunakan fi'il 'amar (kata perintah), namun perintah disini adalah sunnah, karena tidak semua orang mampu mengadakan walimah dalam suatu perkawinan. Perintah wajib menurut Jumhur 'ulama semestinya mampu dilakukan oleh setiap orang. ${ }^{24}$

Ulama al-Zhahiriyyah berbeda dengan Jumhur, dia mengatakan diwajibkan atas setiap orang yang melangsungkan perkawinan untuk mengadakan walimah al-'ursy, baik secara kecil-kecilan maupun secara besar-besaran sesuai dengan keadaan yang mengadakan perkawinan. ${ }^{25}$ Menurut mereka fi'il 'amar mengandung perintah wajib, berdasarkan kaidah usul fikih الأصل في الأمر للوجوب Antara lain yang mereka kemukakan adalah kisah perkawinan Ali bin Abi Thalib dengan Fatimah putri Nabi Muhammad saw. Dalam hadis tersebut juga mengandung kemastian untuk mengadakan walimah. ${ }^{27}$

Kaitanya dengan hukum pelaksanaan walimah pada masyarakat Bugis Bone tidak ada ketentuan jelas. Namun hal yang perlu digaris bawahi bahwa pelaksanaan walimah perkawinan pada masyarakat Bugis Bone sebuah hal yang sangat disakralkan. Pesta adat perkawinan merupakan tradisi turun temurun yang masih sangat kuat mempengaruhi masyarakat Bugis Bone. ${ }^{28}$ Keadaan demikian dianggap sebagai warisan nenek moyang yang tetap kokoh dipengangnya, maka tidak salah jikalau sebuah perkawinan di masyarakat Bugis Bone yang tidak melakukan walimah secara meriah, maka dianggap perkawinan yang masolang (sanksi sosial). Kendatipun demikian, perkawinan yang kadang dianggap masolang (bermasalah) tetap diakui, hanya saja anggapan masyarakat yang kurang terhormat. Oleh karena itu, pelaksanaan walimah perkawinan di masyarakat

\footnotetext{
${ }^{24}$ Syarifuddin Latif, Hukum Perkawinan di Indonesia Buku 1., h. 114-115.

${ }^{25}$ Amir Syarifuddin, Hukum Perkawinan Islam di Indonesia Antara Fiqh Munaqahat dan Undang-undang Perkawinan, h. 156-157.

${ }^{26}$ Syarifuddin Latif, Hukum Perkawinan di Indonesia Buku 1., h. 115.

${ }^{27}$ Abdul Azis Dahlan, Ensiklopedi Hukum Islam, h. 1918.

${ }^{28}$ Abd. Kadir Ahmad MS, Sistem Perkawinan di Sulawesi Selatan dan Sulawesi Barat, h. 138.
} 
Hamzah:

"Interkoneksi Konsep Walimah Perkawinan dalam Hukum Islam dan Hukum Adat Bugis Bone"

Bugis Bone menghendaki keharusan walimah. Konteks keharusan untuk melaksanakan walimah al-'ursy adalah bukti interkoneksi antara anjuran hukum Islam dengan hukum adat masyarakat Bugis Bone.

(b) Waktu Pelaksanaan Walimah

Waktu pelaksanaan walimah sebagaimana yang anjuran dalam hadis yang diriwayatkan Anas bin Malik tidak mengungkap secara jelas. Namun keadaan demikan para ulama mengambil dasar pernikahan Nabi dengan Zainab. Beberapa pendapat di antaranya Mazhab Syafi'i mempunyai dua pendapat, segolongan berpendapat bahwa penyelenggaraan walimah sebelum terjadi hubungan suami istri dengan kata lain setelah dilakukan akad nikah. Pendapat ini dikemukakan oleh Imam al-Mawardi. Segolongan lain berpendapat bahwa penyelenggaran walimah setelah berlangsungnya hubungan suami istri. Pendapat ini dikemukakan oleh Imam Tajuddin dan Subki, karena menurutnya waktu inilah yang terdapat dalam sunah Rasulullah saw. ${ }^{29}$

Menurut Mazhab Maliki mengatakan bahwa pelaksanaan walimah setelah terjadi hubungan antara kedua mempelai, hal ini disandarkan pada Hadis riwayat Bukhari disebutkan bahwa Rasulullah mengudang para sahabat untuk acara walimah sesudah beliau tinggal serumah dengan Zainab. ${ }^{30}$ Ulama mazhab Hambali bahwa waktu pelaksanaan walimah disunnahkan setelah akad nikah berlansung. Sedangkan menurut mazhab Hanafi tidak menentukan waktu yang jelas, karena menurut mereka diserahkan kepada adat kebiasaan setempat. ${ }^{31}$

Relevandi dengan waktu pelaksanaan walimah perkawinan dalam hukum adat masyarakat Bugis Bone dianggap relevan dengan pendapat Imam al-Mawardi pada golongan dengan mazhab Imam Syafi'i, mazhab Hambali setelah akad nikah dan mazhab Hanafi yang menyerahkan pada kebiasaan setempat. Hal ini terbukti bahwa waktu walimah perkawinan masyarakat Bugis Bone dilaksanakan setelah akad nikah.

(c) Bentuk Pelaksanaan Walimah

Hukum adat masyarakat Bugis Bone dalam mengadakan perkawinan, masih tetap berpegang teguh pada nilai agama, budaya dan adat istiadat. Bahkan yang lebih menonjol adalah nilai adat istiadatnya. Begitu banyak proses yang dilalui, mulai dari meminang (mappettu ada), naiknya uang

\footnotetext{
${ }^{29}$ Syarifuddin Latif, Hukum Perkawinan di Indonesia Buku I., h. 117-118.

${ }^{30}$ Sayyid Sabiq, Fiqih Sunnah Jilid 3 (Cet. I; Jakarta: Darul Fath, 2004), h. 128.

${ }^{31}$ Abdul Azis Dahlan, Ensiklopedi Hukum Islam., h. 1918.
} 
Hamzah:

"Interkoneksi Konsep Walimah Perkawinan dalam Hukum Islam dan Hukum Adat Bugis Bone"

belanja (mappaenre doi), Tudang Penni, Mappacci, akad nikah dan resepsi perkawinan. Keseluruhan proses pelaksanaan perkawinan tersebut, akan menghabiskan dana yang begitu besar. Pengaruh adat tersebut tidak terlepas dari proses aktualisasi dan pemahaman agama secara kontekstual.

Fenomena ini sering terjadi dalam masyarakat Bugis Bone yakni pemberian uang belanja dari pihak laki-laki kepada wanita merupakan simbol bahwa pria tersebut akan bertangung jawab dan bersedia menjamin kelangsungan hidup rumah tangga wanita yang dilamarnya. Jumlah uang belanja pun bervariasi sesuai dengan kesepakatan kedua belah pihak, apakah dilaksanakan secara meriah atau sederhana. Lebih dari itu stratifikasi sosial dan kemampuan ekonomi kedua belah pihak sangat menentukan dalam pelaksanaan perkawinan. Bagi kelompok bangsawan acara pelaksanaan pernikahan dilakukan dengan meriah dan terkadang pengaruh adat lebih menonjol. Misalnya dengan dinaikkan uang belanja hinga puluhan juta rupiah menunjukan simbol ketinggian martabat seseorang. Melihat jumlah tersebut nampaknya masyarakat kurang memahami substansi perkawinan itu sendiri. Sekalipun perkawinan itu bersifat sakral, nilai kesakralan itu dapat hilang hanya dengan sebab pelaksanaan perkawinan cenderung materialis.

Bila pelaksanaan pesta perkawinan dikaitkan dengan "أولم ولو بشاة،, menunjukkan sebagai anjuran melakasanakan walimah perkawinan, maka perlu dipahami konteks dimana, kapan dan kondisi masyarakat yang dihadapi Nabi. Pada saat itu, Nabi saw. baru saja berhijrah di Madinah dan kehidupan para sahabatnya secara otomatis belum dalam keadaan mapan, demikian pula dengan Abd. Rahman. Suatu kewajaran bila Nabi menganjurkan dengan “ أولم ولو بشاة،, hal ini menunjukkan kadar minimal dalam pelaksanaan walimah perkawinan. Akan tetapi, bukan berarti adanya pemaksaan pelaksanaan resepsi perkawinan, hal ini tergantung pada keadaan ekonomi bagi yang ingin melaksanakan pesta.

Pelaksanaan walimah perkawinan pada hukum adat masyarakat Bugis Bone dianggap relevan dengan makna hadis Aulim Walau bi Syatin. Kendatipun demikian pelaksanaan walimah pada masyarakat Bugis Bone sedikit berbeda, karena walimah dalam hukum adat Bugis Bone membutuhkan waktu yang cukup lama serta prosesnya begitu panjang. Namun di luar daripada itu makna yang terkadung di dalamnya adalah melaksanakan walimah sebagai bentuk perintah atau anjuran Nabi, sebagaimana Nabi menganjurkan untuk menikah. Bahkan dalam beberapa 
Hamzah:

"Interkoneksi Konsep Walimah Perkawinan dalam Hukum Islam dan Hukum Adat Bugis Bone"

rangkaian acara adat perkawinan masyarakat Bugis Bone selalu mengedepankan perilaku Islami, yakni pada acara tudang penni yang dirangkaikan dengan acara mabbarasanji, mappacci dan mappanre temme, ketiga hal ini secara filosofis mengandung nilai-nilai agama di dalamnya.

Kaitanya dengan hiburan dalam walimah perkawinan dalam hadis Nabi menganjurkan untuk mengumumkan perkawinan أعلنو هدالنكاح dan menganjurkan memukul rebana atasnya واضربوا عليه بالدفوف. Kedaan demikian juga terjadi dalam pelaksanaan walimah perkawinan masyarakat Bugis Bone, selalu dimeriahkan oleh hiburan elekton, karaoke atau sejenisnya yang terkadang kurang etis. Akan tetapi perlu ditegaskan bahwa hal demikian bukan lagi hukum adat masyarakat Bugis Bone, karena adat Bugis Bone sangat menjunjung tinggi nilai-nilai siri' serta perilaku terpuji dan sopan santun yang disebut dengan mappakiade. Perilaku demikian dianggap sebagai modernisasi yang berkembang di tengah-tengah masyarakat dan sulit lagi untuk dipisahkan.

Pelaksanaan walimah al-ursy pada masyarakat Bugis Bone dengan hukum Islam, sesuai dengan petunjuk hadis Aulim Walau bi Syatin. Tingkat relevansinya hanya sebatas pada kebolehannya, tidak sampai kepada prosesnya sacara keseluruhan. Hak ini terbukti bahwa, pelaksanaan walimah perkawinan menurut makna hadis Aulim Walau bi Syatin lebih mengedepankan kesederhanaan, di samping itu tergambar pula pelaksanaan walimah yang sifatnya tidak dipaksakan, karena adanya kata ولو (walaupun). Sedangkan dalam hukum adat pelaksanaan walimah pada masyarakat Bugis Bone, proses pelaksanaannya terlalu panjang dan memerlukan waktu yang cukup lama. Hal ini dikarenakan banyak hal-hal yang harus dipenuhi sebelum acara pesta perkawinan.

\section{Penutup}

Interkoneksi hukum Islam dan hukum adat terhdap konsep walimah perkawinan memiliki tingkatan yang relevan dalam berbagai hal. Konsep pelaksanaan walimah dalam hukum Islam sifatnya sederhana sesuai dengan kemampuan kedua mempelai. Pelaksanaan walimah perkawinan antara hukum Islam dan hukum adat Bugis Bone dianggap relevan dari segi hukum melakukan walimah. Aspek hukum yang mencerminkan koneksi antara hukum adat dengan 
hukum Islam terletak pada prinsip hukum Islam yang sejalan. Prinsip hukum adat bugis Bone dalam pelaksanaan walimah perkawinan berasakan adat istiada. Dalam hukum Islam dikenal dengan al-urf, dan adat yang dilaksanakan tidak bertentangan dengan prinsip hukum Islam, sehingga keduanya memiliki interkoneksi dan korelasi yang relevan. 


\section{Daftar Pustaka}

Alquran Karim

Ali, Atabik dan A. Zuhdi Muhdlor. Kamus Kontemporer Arab Indonesia. Cet. VIII; Yongyakarta: Multi Karya Grafika, 2003.

Ahmad, Abd. Kadir Sistem Perkawinan di Sulawesi Selatan dan Sulawesi Barat. Cet. I; Makassar: Indobis, 2006.

al-Bukhari, Abu Abdillah Muhammad bin Ismail. Shahih al-Bukhari, Jilid III. Beirut: Dar al-Fikr, t.th.

Bisri, Ilhami. Sistem Hukum Indonesia Prinsip-Prinsip dan Implementasi Hukum di Indonesia. Cet. I; Jakarta: PT Raja Grafindo Persada, 2004.

Dahlan, Abdul Azis. Ensiklopedia Hukum Islam. Cet. I; Jakarta: Ictiar Baru Van Hoeva, 1996.

Hanbal, Abū Abdillah Ahmad Ibn. Musnad Ahmad bin Hanbal, Juz III. Bairut: al-Maktab al-Islāmi, 1978.

Ismail, M. Syuhudi. Metodologi Penelitian Hadis. Cet.I; Jakarta: Bulan Bintang, 1992.

al-Jamal, Ibrahim Muhammad. Fiqih Wanita (Terjemahan Anshori Umar). Cet. I; Semarang: CV. Asy-Syifa', 1986.

Lamallongeng, Asmat Riady. Dinamika Perkawinan Adat dalam Masyarakat Bugis Bone. Dinas Kebudayaan dan Pariwisata, 2007.

Latif, Syarifuddin. Budaya Perkawinan Masyarakat Bugis Tellumpoccoe Perspektif Hukum Islam (Disertasi, Program Pascasarjana Universitas Islam Negeri Alauddin Makassar, 2008

-Hukum Perkawinan di Indonesia Buku 1. Cet. I; Watampone: CV Berkah Utami, 2010.

Munawir, Ahmad Warso. Kamus Arab Indonesia. t.c. Yongyakarta: Pustaka Progressif, 1984.

al-Nawawiy, Abu Zakariya Yahya bin Syaraf. Shahih Muslim bin Syarh alNawawiy, jilid IX. Mesir: al-Matba'ah al-Misriyah, 1924

Pelras, Cristian. Manusia Bugis. t.c. Jakarta: Forum Jakarta-Faris École Français, 2006.

Syarifuddin, Amir. Hukum Perkawinan Islam di Indonesia antara Fiqih Munaqahat dan Undang-undang Perkawinan. Cet. V; Jakarta: Kencana, 2006. .

Sabiq, Sayid. Fiqh as-Sunnah Jilid. II, Cet. VIII; Beirut: Dar al-Kitab alAraby, 1987 M/1407 H.

Zuhaly, Muhammad. Fikih Munakahat Kajian Fiqih Pernikahan dalam Perspektif Mazhab Syafi'I . Cet. I; Surabaya: CV Imtiyaz, 2013. 